\title{
Enzymatic Profiling and Feeding Preferences of Catla: Catla Catla, Rohu: Labeo rohita and Mrigala: Cirrhinus mrigala in Rural Polyculture Ponds
}

\author{
Gajender Singh ${ }^{1}$, Anita Bhatnagar ${ }^{2}$, Kalla Alok ${ }^{3}$ and Singh Ashneel Ajay ${ }^{*}$ \\ ${ }^{1}$ Haryana Kisan Ayog, Anajmandi Sector - 20, Panchkula, Haryana, India \\ ${ }^{2}$ Department of Zoology, Kurukshetra University Kurukshetra, India \\ ${ }^{3}$ Department of Fisheries, College of Agriculture, Fisheries and Forestry, Fiji National University, Nasinu, Fiji \\ ${ }^{4}$ School of Science and Technology, Department of Science, The University of Fiji, Fiji
}

\begin{abstract}
This study was aimed at understanding the enzymatic profile of three major Indian carps in managed and unmanaged polyculture systems in the Hisar district, Haryana India. The three species were catla (Catla calta), rohu (Labeo rohita) and mrigala (Cirrhinus mrigala). Analysis of gut contents of $C$. mrigala from both the ponds was significantly $(p<0.05)$ dominated by phytoplankton. $L$. rohita gut had similar values of both phytoplankton and zooplankton while $C$. catla gut was significantly dominated by zooplanktons. The specific cellulase and amylase activities were higher in C. mrigala. It was further observed that these activities are higher in managed ponds as compared to the unmanaged ponds. $L$. rohita revealed elevated levels of protease and amylase activities which supported the omniplanktivorous nature of the fish. Analysis of digestive enzymes from the gut of C. mrigala revealed more lipase, cellulase and amylase in comparison to other enzymes. It can be concluded that $C$. mrigala was phytoplanktivorous, $L$. rohita was omniplanktivorous and $C$. catla was zooplanktivorous. Fishes reared in managed ponds seemed to have higher enzymatic activities in the gut advocating higher growth. The results of the study enhance our understanding of the feeding patterns at different stratus levels within the available nutrition in polyculture systems.
\end{abstract}

Keywords: Polyculture system; Digestive enzymes; Gut contents; Exogenous enzyme; Enzyme producing bacteria; Trophic level

\section{Introduction}

Fish culturing in small water bodies is quite commonly practiced in the Asia region as well as parts of Africa where culture fisheries are established in reservoirs, communal lakes and village ponds / private farm ponds [1-8]. For pond productions based primarily on natural food, achieving a good yield requires sufficient understanding of the plankton production system and limnetic ecology.

The abundance of the species composition and condition of the aquatic organisms in the natural community are related directly with the water quality. The effect of stress due to anthropogenic activities manifests themselves in the pond biota viz. changes in the pattern of distribution, elimination of the sensitive species, changes in diversity and subtle morphological and physiological changes [5,9-11]. The productivity level of a fish pond is dependent upon suitable pond ecological conditions, growth and abundance of fish food organisms.

Digestion depends on the physical state of food, as well as the kind and quality of enzymes secreted. Activity of digestive enzymes has been reported to change with the feeding habits of fish or availability of fish food organisms [12-14]. Improved understanding of pond fish digestive enzyme profiling can provide a better insight to explaining the digestive processes of the pond fishes that operate under variable conditions of feeding. From such understanding, the incorporation of appropriate enzymes can help in increasing the digestibility and improving the growth performance of fish.

Various works have been carried out on endogenous fish digestive enzymes by a host of workers [13-17]. Despite this, there is shortage of material on the subjects of enzyme production, the sources of these enzymes and their significance in fishes. Previous works have studied the native microflora of aquaculture fish for various objectives. These include microbial spoilage mechanisms, the environmental relationship with fish microflora [18-20] and profiling of the indigenous microflora antibiotic resistance [21-23]
Fish tend to continuously intake large quantities of microbes in their gut system from the surrounding water, food and sediments populated with bacteria [24]. Fish gastrointestinal tract is usually colonized by various types of heterotrophic bacteria in large numbers which include both aerobic and anaerobic bacteria. Despite various ecological research works on the gut bacterial flora in fish being previously available [2527], reports concerning their functions have only appeared recently. There are some reports on microbiological enzymatic production in fish intestinal tract $[13,14,17,28-33]$, however studies on the enzyme producing bacteria distribution in the gut of fish is quite limited. But it is confirmed that there are variations in the quality and quantity of these enzyme producing microorganisms the amounts of enzymes present in fish gastrointestinal tracts also vary.

Catla Catla catla, mrigala Cirrhinus mrigala and rohu Labeo rohita are three widely utilized and significantly important polyculture species in India [34,35], however there is insufficient information on the digestive physiology and feeding preferences of these three species. This study aims to provide a deeper insight on the digestive enzymatic activities and whether the three fish species in polyculture arrangement are occupying different trophic levels in terms of preferred foods for permitting feeding and good production.

*Corresponding author: Singh Ashneel Ajay, School of Science and Technology Department of Science, The University of Fiji, Fiji, Tel: +679 664 0600; E-mail: ajaymsp1@gmail.com

Received November 02, 2018; Accepted November 27, 2018; Published November 30, 2018

Citation: Singh G, Bhatnagar A, Alok K, Ajay SA (2018) Enzymatic Profiling and Feeding Preferences of Catla: Catla Catla, Rohu: Labeo rohita and Mrigala: Cirrhinus mrigala in Rural Polyculture Ponds. J Aquac Res Development 9: 553. doi: 10.4172/2155-9546.1000553

Copyright: @ 2018 Singh G, et al. This is an open-access article distributed unde the terms of the Creative Commons Attribution License, which permits unrestricted use, distribution, and reproduction in any medium, provided the original author and source are credited. 


\section{Materials and Methods}

\section{Study area}

Four polyculture village ponds were selected as study sites in the Hisar district, state of Haryana, India with the geo-referenced location (Longitude, $75^{\circ}-72^{\prime} \mathrm{E}$ and Latitude, $29^{\circ}-15^{\prime} \mathrm{N}$ ) as shown in Figure 1. Two of the ponds were unmanaged pond but with cattle and domestic effluent intakes. The other two ponds were managed type pond with control of household effluent intake and cattle movement. The four ponds are geographically evenly located with similar soil characteristics and exposed to sunlight. The physicochemical and biological characteristics of the unmanaged and managed ponds are shown in Table 1.

\section{Analysis of gut contents and forage ratio}

Specimens of live and mature freshwater fishes of the species Labeo rohita, Catla catla and Cirrhinus mrigala from each of the selected ponds were sampled using cast net on fortnightly between the months of March 2011 and February 2012. 120 mature fish of each species (360 fish) were taken for analysis from each pond (total 1440 fish) with a weight range of $248.00 \mathrm{~g}$ to $298.00 \mathrm{~g}$. Fish were dissected in ice surface and the digestive tracts were removed together with the contents and preserved in 5\% formalin. The gut contents were then analysed both quantitatively and qualitatively following the procedure outlined in Garg [36]

\section{Forage ratio}

Plankton samples were collected from each of the ponds and analysed. They were classified up to the genus level. Equation 1 shown below was used for the forage ratio.

$$
F=\frac{g}{w}
$$

Where $F$ represents the forage ratio, $g$ represents the percentage of organisms that are present in gut contents and $w$ represents the percentage of organisms present in the water/environment sample. When the value of $F=1$, it indicates random food selection from the surroundings, $F>1$ indicates active preference of the item by the fish, $F<1$ is an indication that the fish avoids the food item. $F$ value is directly proportional to the level of food preference.

\section{Digestive physiology analysis}

The extracted alimentary tracts of fish were homogenized with 10 parts cold $0.89 \% \mathrm{NaCl}$ solution [17]. The homogenate was used for different measurements. Bovine Serum Albumin (BSA) was used as $1 \%$ substrate to measure the proteolytic enzyme activity using the methods presented in Walter [37]. Estimation of proteins was done using the methods of Lowery [38]. The methods of Bernfeld [39] were used for measurement of the amylase activity in the intestinal tract using starch solution as $1 \%$ substrate. Microcrystalline cellulose was used as $1 \%$ substrate to estimate the intestinal cellulase activity.

\section{Estimation of intestine lipase enzyme activity}

Two volumes of ice-cold acetone were added to intestinal tissue which was homogenized in a homogenizer. Filtration of the homogenate was done and washed in sequence with acetone, acetone-ether mixture and ether. The obtained residue was air dried and one gram was added to ice-cold water and stirred for 15 minutes before use. The contents were subjected to centrifugation at $15,000 \mathrm{rpm}$ for 10 minutes. The supernatant was utilized as a crude enzyme extract and measurement of lipase activity was done using the procedure outlined in Colowick and Kaplan [40].

\section{Estimation of liver glycogen}

The liver was taken out from the fish and the excess of blood was immediately removed with filter paper. The liver was then transferred to a test-tube which contained $2.0 \mathrm{~mL}$ of $30 \% \mathrm{KOH}$ solution/gram of liver. It was then placed in a water bath at boiling temperature for 90 minutes to digest the tissue and allowed to cool. Following this procedure, two volumes of $95 \%$ ethanol was added to the sample and placed in a water bath at boiling temperature. The samples were then left overnight, under cold conditions and centrifuged at $3000 \mathrm{rpm}$ for 20 minutes. After this, the obtained precipitate was dissolved in 5-10 $\mathrm{mL}$ of lukewarm water. For glycogen, the precipitate was precipitated again by addition of two volumes of $95 \%$ ethanol. The obtained precipitate was collected through centrifugation at $5000 \mathrm{rpm}$ for 1520 minutes at a temperature of $4^{\circ} \mathrm{C}$ followed by several washings using $60 \%(\mathrm{v} / \mathrm{v})$ ethanol. The obtained precipitate was further transferred with $2 \mathrm{~N} \mathrm{H}_{2} \mathrm{SO}_{4}$ /gram of liver. The contents were hydrolyzed in a water bath at boiling temperature for 3-4 hours. After cooling the contents were neutralized with $6 \mathrm{~N} \mathrm{NaOH}$ (phenol red was used as an indicator). The volume was made to and followed by filtration. An appropriate aliquot was used for determination of glucose content. The factor of 0.93 was utilized in the conversion of glucose to glycogen. Sugar level was determined following the methods in Dubios [41].

\section{Statistical analysis}

ANOVA variance analysis and Duncan Multiple range statistical test was carried out to determine if significant differences existed between the different ponds for each parameter. Coefficient of correlation was also calculated. All statistical analysis was carried out using the SPSS package.

\section{Results}

\section{Gut content analysis and forage ratio of Indian major carps}

\section{Managed ponds of district Hisar}

Cirrhinus mrigala: Analysis of gut contents of C. mrigala samples collected from managed ponds of district Hisar indicated the presence of members of Bacillariophyceae (31.17\%) along with some unidentified matter and debris $(40.48 \%)$ (Table 1 ). Forage ratio indicating the preferred food items were calculated and results showed significantly $(p<0.05)$ high value of forage ratio for Cyclotella (2.45), Navicula (1.83) and Synedra (1.63) for C. mrigala. The value for zooplankton was much lower indicating that C. mrigala is a phytoplanktivorous and Cyclotella, Navicula and Synedra are its preferred food items (Tables 2 and 3).

Labeo rohita: Analysis of gut contents of L. rohita collected from managed ponds of district Hisar indicated the presence of member of Bacillariophyceae (14.20\%), Chlorophyceae (13.20\%), Cladocera (12.84\%) and Copepoda (9.47\%) along with some unidentified matter and debris (43.18\%) (Table 2). The preferred food items that were foraged appear in Table 3. The results showed significant $(p<0.05)$ value of Microspora (3.21), Moina (3.20) and Diaptomous (2.56) indicating that L. rohita is omnivorous and Microspora, Moina and Diaptomous are preferred food items.

Catla catla: Analysis of gut contents of C. catla collected from managed ponds of district Hisar indicated the presence of member of Copepoda (15.20\%) and Cladocera (11.40\%) along with some unidentified matter and debris $(46.80 \%)$ (Table 1). Forage ratio 
Citation: Singh G, Bhatnagar A, Alok K, Ajay SA (2018) Enzymatic Profiling and Feeding Preferences of Catla: Catla Catla, Rohu: Labeo rohita and Mrigala: Cirrhinus mrigala in Rural Polyculture Ponds. J Aquac Res Development 9: 553. doi: 10.4172/2155-9546.1000553

Page 3 of 8

\begin{tabular}{|c|c|c|c|c|}
\hline Parameters & H1 & $\mathrm{H} 2$ & H3 & H4 \\
\hline Water Temp. $\left({ }^{\circ} \mathrm{C}\right)$ & $22.12 \pm 1.40$ & $22.24 \pm 1.36$ & $23.57 \pm 1.06$ & $23.92 \pm .90$ \\
\hline $\mathrm{pH}$ & $9.08 \pm 0.09$ & $8.19 \pm 0.02$ & $8.17 \pm 0.08$ & $8.12 \pm 0.13$ \\
\hline Conductivity $\left(\mu \mathrm{S} \mathrm{cm}{ }^{-1}\right)$ & $4201.94 \pm 56.60$ & $1618.33 \pm 10.45$ & $1023.44 \pm 84.40$ & $427.66 \pm 15.97$ \\
\hline Salinity ppt & $2.0 \pm 0.02$ & 0.0 & 0.0 & 0.0 \\
\hline Free $\mathrm{CO}_{2}\left(\mathrm{mg} \mathrm{L}^{-1}\right)$ & Absent & $22.55 \pm 1.42$ & $11.50 \pm .95$ & $13.10 \pm 1.55$ \\
\hline Dissolved oxygen $\left(\mathrm{mg} \mathrm{L}^{-1}\right)$ & $3.93 \pm 0.08$ & $6.26 \pm 0.03$ & $7.21 \pm 0.05$ & $7.51 \pm 0.06$ \\
\hline $\mathrm{BOD}\left(\mathrm{mg} \mathrm{L}^{-1}\right)$ & $2.70 \pm 0.13$ & $3.04 \pm 0.10$ & $2.45 \pm 0.05$ & $2.38 \pm 0.10$ \\
\hline Carbonate Alkalinity $\left(\mathrm{mg} \mathrm{L}^{-1}\right)$ & $57.21 \pm 4.25$ & Nil & Nil & Nil \\
\hline Biocarbonate Alkalinity $\left(\mathrm{mg} \mathrm{L}^{-1}\right)$ & $429.77 \pm 25.64$ & $382.83 \pm 14.67$ & $240.55 \pm 9.16$ & $168.16 \pm 2.34$ \\
\hline Total alkalinity $\mathrm{mg} \mathrm{L}^{-1}$ ) & $486.98 \pm 22.82$ & $382.83 \pm 14.67$ & $240.55 \pm 9.16$ & $168.16 \pm 2.34$ \\
\hline Chloride $\left(\mathrm{mg} \mathrm{L}^{-1}\right)$ & $221.26 \pm 11.16$ & $193.18 \pm 13.04$ & $115.65 \pm 22.55$ & $9.42 \pm .38$ \\
\hline Total Hardness (mg L-1) & $543.72 \pm 14.60$ & $206.33 \pm 6.6$ & $234.83 \pm 28.21$ & $172.11 \pm 3.24$ \\
\hline Calcium (mg L-1) & $73.26 \pm 10.65$ & $41.57 \pm 1.69$ & $43.54 \pm 11.76$ & $26.45 \pm 4.06$ \\
\hline Magnesium $\left(\mathrm{mg} \mathrm{L}^{-1}\right)$ & $87.96 \pm 8.88$ & $25.04 \pm 2.40$ & $30.75 \pm 1.05$ & $25.87 \pm 2.79$ \\
\hline O-phosphate $\left(\mathrm{mg} \mathrm{L}^{-1}\right)$ & $2.3 \pm 0.06$ & $1.93 \pm 0.04$ & $0.74 \pm 0.02$ & $0.46 \pm 0.02$ \\
\hline Total phosphate $\left(\mathrm{mg} \mathrm{L}^{-1}\right)$ & $2.87 \pm 0.10$ & $2.54 \pm 0.03$ & $1.15 \pm 0.05$ & $0.63 \pm 0.05$ \\
\hline Total ammonia $\left(\mathrm{mg} \mathrm{L}^{-1}\right)$ & $2.05 \pm 0.56$ & $1.36 \pm 0.35$ & $0.52 \pm 0.04$ & $0.59 \pm 0.11$ \\
\hline Plankton Population $\left(\mathrm{L}^{-1}\right)$ & $3780.00 \pm 193.21$ & $3893.33 \pm 238.62$ & $3520 \pm 208.65$ & $3333.33 \pm 156.86$ \\
\hline Phytoplankton $\left(\mathrm{L}^{-1}\right)$ & $2153.33 \pm 143.35$ & $2076.66 \pm 172.74$ & $2206.66 \pm 157.73$ & $2083.33 \pm 113.02$ \\
\hline Zooplankton $\left(\mathrm{L}^{-1}\right)$ & $1626.66 \pm 83.94$ & $1816.66 \pm 151.17$ & $1313.33 \pm 98.55$ & $1037.33 \pm 183.00$ \\
\hline
\end{tabular}

All values are mean \pm S.E. of mean

Table 1: Physicochemical and biological characteristics of the unmanaged ponds $(\mathrm{H} 1$ and $\mathrm{H} 2)$ and managed ponds $(\mathrm{H} 3-\mathrm{H} 4)$ of $\mathrm{Hisar}$ district.

\begin{tabular}{|c|c|c|c|}
\hline \multicolumn{4}{|c|}{ Hisar managed ponds } \\
\hline Variables & Catla catla & Labeo rohita & Cirrhinus mrigala \\
\hline \multicolumn{4}{|c|}{ Phytoplankton } \\
\hline Debris & 40.48 & 43.18 & 46.80 \\
\hline Bacillriophyceae & 31.17 & 14.20 & 9.5 \\
\hline Chlorophyceae & 5.66 & 13.20 & 9.5 \\
\hline \multicolumn{4}{|c|}{ Zooplankton } \\
\hline Rotifera & 11.33 & 7.10 & 7.6 \\
\hline Cladocera & 5.66 & 12.84 & 11.4 \\
\hline Copepoda & 5.66 & 9.47 & 15.2 \\
\hline \multicolumn{4}{|c|}{ Hisar unmanaged ponds } \\
\hline Variables & Catla catla & Labeo rohita & Cirrhinus mrigala \\
\hline \multicolumn{4}{|c|}{ Phytoplanton } \\
\hline Debris & 42.39 & 45.66 & 47.72 \\
\hline Bacillriophyceae & 24.69 & 19.55 & 6.83 \\
\hline Chlorophyceae & 12.32 & 6.52 & 4.54 \\
\hline \multicolumn{4}{|c|}{ Zooplankton } \\
\hline Rotifera & 6.16 & 4.34 & 11.36 \\
\hline Cladocera & 8.22 & 8.69 & 13.62 \\
\hline Copepoda & 6.16 & 15.21 & 15.90 \\
\hline
\end{tabular}

Table 2: Gut content analysis of Labeo rohita, Cirrhinus mrigala and Catla catla from the managed and unmanaged ponds of the Hisar district. All values are in percentage of total contents.

indicating the preferred food items were calculated (Table 3) and results exhibited significantly $(p<0.05)$ high value of forage ratio for Cyclops (2.75) and Branchionus (1.83). This indicated that C. catla is zooplaktovorous and Cyclops and Branchionus are its preferred food items.

\section{Unmanaged ponds of district Hisar}

Cirrhinus mrigala: Analysis of gut contents of C. mrigala collected from unmanaged ponds of district Hisar indicated the presence of member of Bacillariophyceae (24.69\%) and Chlorophyceae (12.32\%) along with some unidentified matter and debris (42.39\%) (Table 2). Forage ratio indicating the preferred food items were calculated (Table $4)$ and results showed significantly $(p<0.05)$ high value of forage ratio for Microspora (3.64), Synedra (2.73) and Navicula (2.27) for C. mrigala whereas the value for zooplankton was much lower indicating that $C$. mrigala is a phytoplanktivorous and Microspora, Synedra and Navicula are its preferred food items.

Labeo rohita: Analysis of gut contents of L. rohita collected from unmanaged ponds of district Hisar indicated the presence of member of Bacillariophyceae (19.55\%) and Copepoda (15.21\%) along with some unidentified matter and debris (45.66\%) (Table 2). Forage ratio indicating the preferred food items were calculated (Table 4 ) and results showed significantly $(p<0.05)$ high value of forage ratio for Cyclops (2.20), Synedra (1.85), Closterium (1.54) and Daphnia (1.54) indicating that L. rohita is omnivorous and Cyclops, Synedra, Closterium and Daphnia are its preferred food items. 
Citation: Singh G, Bhatnagar A, Alok K, Ajay SA (2018) Enzymatic Profiling and Feeding Preferences of Catla: Catla Catla, Rohu: Labeo rohita and Mrigala: Cirrhinus mrigala in Rural Polyculture Ponds. J Aquac Res Development 9: 553. doi: 10.4172/2155-9546.1000553

Page 4 of 8

\begin{tabular}{|c|c|c|c|}
\hline Variables & Cirrhinus mrigala & Labeo rohita & Catla catla \\
\hline \multicolumn{4}{|c|}{ Phytoplankton } \\
\hline Synedra sp. & 1.63 & 1.07 & 1.22 \\
\hline Navicula sp. & 1.83 & 1.20 & 0.68 \\
\hline Cyclotella sp. & 2.45 & - & 0.91 \\
\hline Closterium sp. & 0.91 & 0.80 & 1.03 \\
\hline Microspora sp. & - & 3.21 & - \\
\hline Total Phytoplankton & 6.82 & 6.28 & 3.84 \\
\hline \multicolumn{4}{|c|}{ Zooplankton } \\
\hline Branchionus sp. & 1.22 & 1.60 & 1.83 \\
\hline Diaptomous sp. & 0.73 & 2.56 & 1.65 \\
\hline Daphnia sp. & 0.91 & - & 1.37 \\
\hline Moina sp. & - & 3.20 & - \\
\hline Cyclops sp. & - & - & 2.75 \\
\hline Total Zooplankton & 2.86 & 7.36 & 7.60 \\
\hline
\end{tabular}

Table 3: Forage ratio of Labeo rohita, Cirrhinus mrigala and Catla catla from the managed ponds of the Hisar district.

\begin{tabular}{|c|c|c|c|}
\hline Variables & Cirrhinus mrigala & Labeo rohita & Catla catla \\
\hline \multicolumn{4}{|c|}{ Phytoplankton } \\
\hline Synedra sp. & 2.73 & 1.85 & 0.62 \\
\hline Navicula sp. & 2.27 & 1.02 & 0.51 \\
\hline Cyclotella sp. & - & 1.23 & 1.23 \\
\hline Closterium sp. & - & 1.54 & 1.02 \\
\hline Microspora sp. & 3.64 & - & - \\
\hline Total Phytoplankton & 8.64 & 5.64 & 3.38 \\
\hline \multicolumn{4}{|c|}{ Zooplankton } \\
\hline Branchionus sp. & 1.17 & - & 2.20 \\
\hline Diaptomous sp. & 1.36 & 1.02 & 2.57 \\
\hline Daphnia sp. & 1.36 & 1.54 & 1.54 \\
\hline Keretella sp. & - & 1.23 & - \\
\hline Cyclops sp. & 0.78 & 2.20 & 1.32 \\
\hline Total Zooplankton & 4.67 & 5.99 & 7.63 \\
\hline
\end{tabular}

Table 4: Forage ratio of Labeo rohita, Cirrhinus mrigala and Catla catla from the unmanaged ponds of the Hisar district.

Catla catla: Analysis of gut contents of C. catla collected from unmanaged ponds of district Hisar indicated the presence of member of Copepoda (15.90\%) and Cladocera (13.62\%) along with some unidentified matter and debris (47.72\%) (Table 2). Forage ratio indicating the preferred food items were calculated (Table 4) and results showed significantly $(p<0.05)$ high value of forage ratio for Diaptomous (2.57) and Branchionus (2.20). This indicated that C. catla is zooplanktivorous and that Diaptomous and Branchionus are its preferred food items.

\section{Intestinal enzymes and liver glycogen of Indian major carps}

Managed pond of district Hisar: Total and specific protease and liver glycogen activity were high but total and specific lipase activity, amylase and cellulase were low in C. catla in comparison to L. rohita and C. mrigala. For L. rohita total and specific protease, amylase and cellulase activity, lipase activity and liver glycogen were in moderate quantity. In the case of $C$. mrigala total and specific protease and live glycogen activity were much lower but total and specific lipase activity; amylase and cellulase were much higher in comparison to L. rohita and C. catla (Figures 2, 3 and 4).

Unmanaged pond of District Hisar: The activity of digestive enzymes and liver glycogen followed the same trend as that in managed pond (Figures 2, 3 and 4).

\section{Discussion}

The natural food of the fishes under this work has been studied in various research works by examination of the gastrointestinal contents [42-47] and it was revealed that they were planktivorous. Analysis of gut contents of C. mrigala indicated that apart from debris and decaying matter, Bacillariophyceae and Chlorophyceae were the dominant group. Although detritus/debris was high, the preferred food items as determined by calculating the forage ratios were Cyclotella, Spirogyra, Synedra and Closterium indicating that fish was a herbivore i.e., phytoplankton feeder or phytoplanktivorous. Forage ratio for zooplanktons was always lower than phytoplanktons in case of $C$. mrigala. Khabade [46] has also reported similar results.

Analysis of the gut contents of L. rohita from all the ponds indicated large quantities of members of Bacillariophyceae, Chlorophyceae, Copepoda and Cladocera. High forage ratio was observed for Spirogyra, Cyclotella, Cyclops \& Diaptomus and sometimes Daphnia. No significant difference was observed in the gut content data for unmanaged and managed ponds indicating that $L$. rohita was Omniplanktivorus fish. Similar results have been reported in Mohanty, [48] and Majumder [49]. Similarly, for C. catla, irrespective of the culture practice, the analysis of gut contents revealed the dominance of Cladocera, Copepoda or Rotifera groups i.e., zooplankton along with large quantities of mud debris. Similar results have been reported in Khan and Siddiqui [50]. Here forage ratio was low for phytoplanktons indicating that the fish 


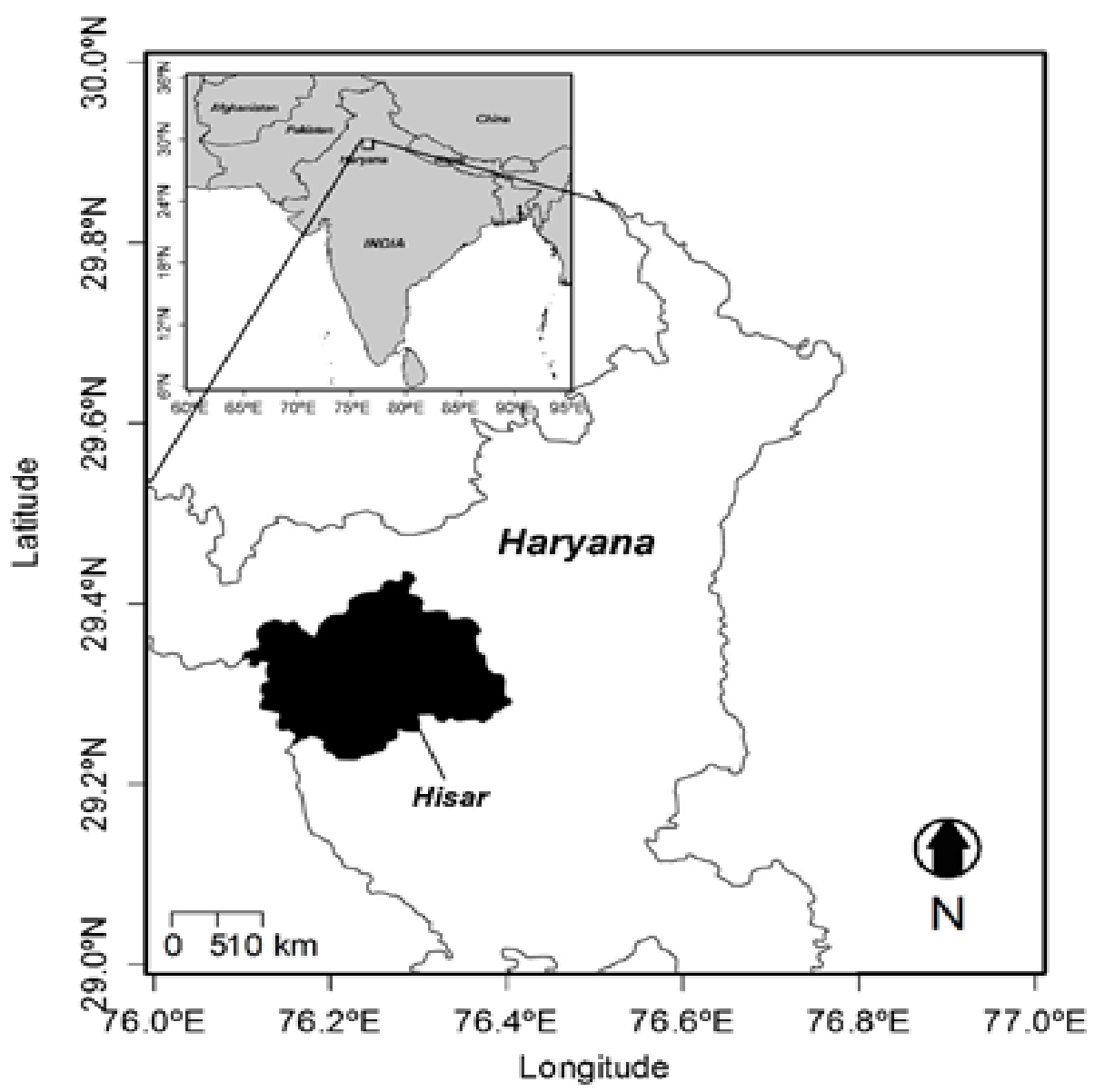

Figure 1: Four polyculture village ponds, in the Hisar district, state of Haryana, India with the geo-referenced location (Longitude, $75^{\circ}-72^{\prime} \mathrm{E}$ and Latitude, $29^{\circ}-15^{\prime} \mathrm{N}$ ).

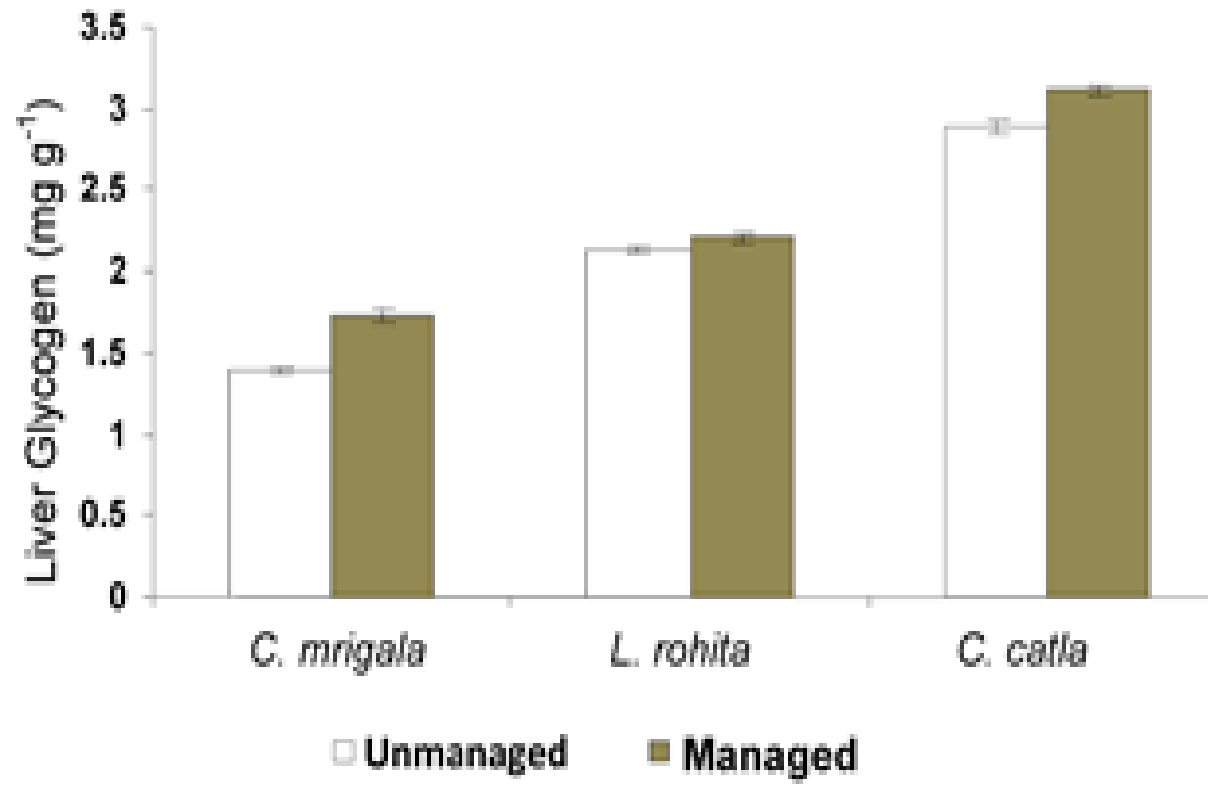

Figure 2: Figure showing intestinal enzymes and liver glycogen of Indian major carps. 


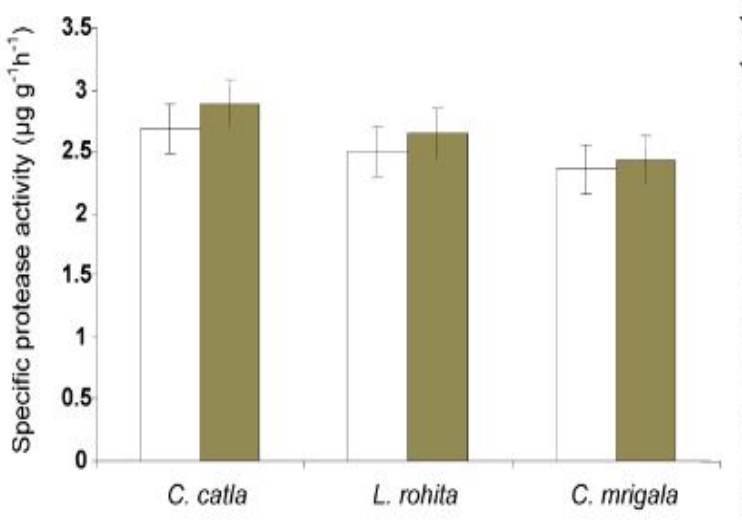

Unmanaged Managed

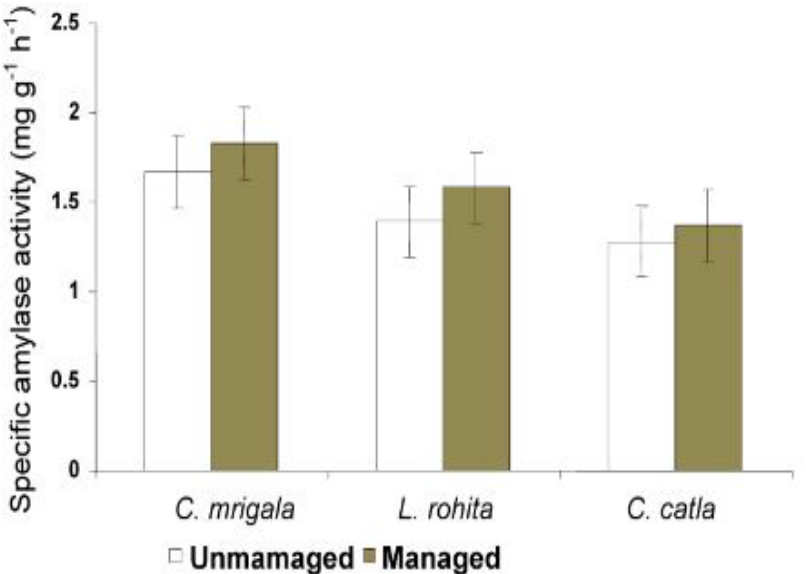

Figure 3: Figure showing specific protease activity.

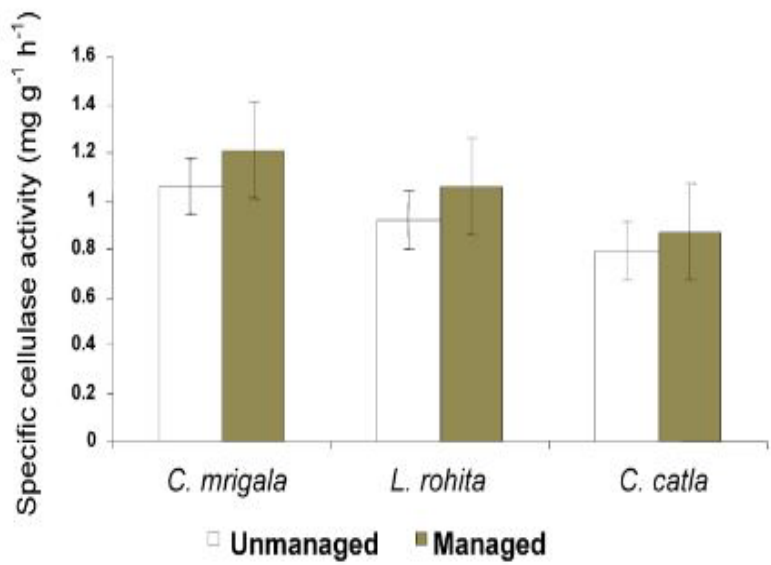

Figure 4: Figure showing specific cellulase activity.

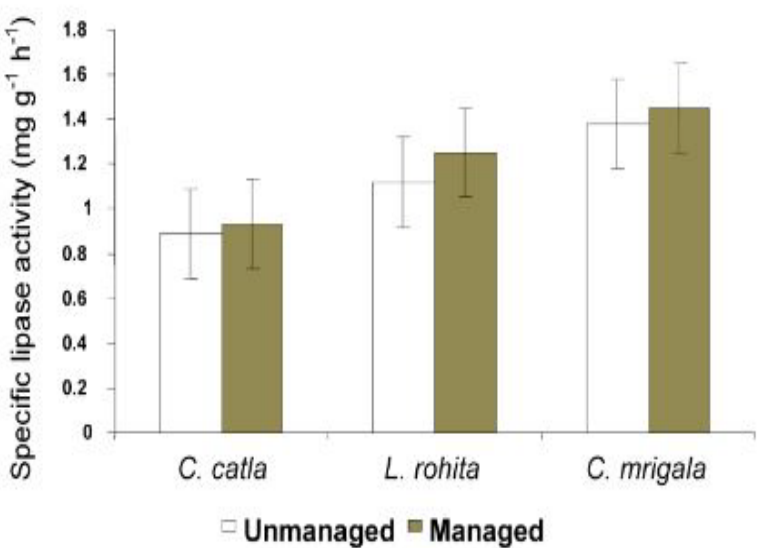

$\square$ Unmanaged $\square$ Managed was zooplanktivorous. These results provide a clearer distinction of the occupation of different stratus by each fish species for feeding purposes among the food that was made available in the polyculture village pond system. This allows for a deeper understanding of how good production tends to occur.

The ability of fish to use nutrients from food depends upon several factors and digestive enzyme is one of them. It was observed that specific cellulase and amylase activities were higher in C. mrigala which also advocate the phytoplanktivorous feeding habit. It was further observed that these activities are higher in the managed ponds as compared to the unmanaged ponds. The amylase activity in the gastrointestinal tract of herbivorous carps is more intense compared to carnivorous fishes as suggested in Dhage [15], Sarbahi [51] and Philips [52]. Bairagi [30] reported the presence of amylolytic bacteria (responsible for exogenous amylase production) from the gut of C. mrigala and C. catla even after 24 hrs of starvation.

Cellulase activity was high in case of C. mrigala. Barrington [42], Fish [53] and Yokoe and Yasumasu [54] suggested that there is no cellulase available in fish. Shcherbina and Kazlawlene [55] explained that there is endogenous secretion of cellulase in the anterior section of the carp digestive tract. Lesel [28] estimated cellulase activity for grass carp and gold fish. Bairagi [30] made observations of cellulolytic bacteria in considerable amount from gut of C. catla. Both C. catla and $L$. rohita had lower celullase activity than C. mrigala. Cellulase producing bacteria have been previously islolated from C. mrigala and L. rohita $[33,56]$.

Detection of elevated levels of protease and amylase in L. rohita further support the omniplanktivorous nature of the fish. Das and Tripathi [17] have also determined that fish having omnivorous feeding habits have high levels of amylase activity in their guts. Bairagi [30] reported the presence of considerable amylolytic and proteolytic bacterial load in the gastrointestinal tract of $L$. rohita and suggested that along with endogenous there is also exogenous source of protease and amylase.

Analysis of digestive enzymes from the gut of $C$. mrigala revealed more lipase in comparison to other enzymes. Dhage [15] also reported that lipase activity is more concentrated in the intestine of $C$. mrigala. Liver glycogen was high in C. catla, supporting the zooplanktivorous nature of the fish as revealed by gut content analysis. Hepatic glycogen was low in C. mrigala and L. rohita. Bhattacharya [57] reported that 
Citation: Singh G, Bhatnagar A, Alok K, Ajay SA (2018) Enzymatic Profiling and Feeding Preferences of Catla: Catla Catla, Rohu: Labeo rohita and Mrigala: Cirrhinus mrigala in Rural Polyculture Ponds. J Aquac Res Development 9: 553. doi: 10.4172/2155-9546.1000553

hepatic glycogen is hydrolyzed by $\alpha$-amylase and $\beta$-amylase and later metabolized in the glycolytic sequence. In the present study amylase was high in C. mrigala and L. rohita and thus the low glycogen level. Fishes reared in managed ponds had higher enzymatic activities in the gut advocating higher growth. Glycogen levels are also affected by the population densities as shown in Chatterjee [58].

Digestion depends on the physical state of food, as well as the kind and quantity of enzymes secreted. It is reported that in addition to endogenous digestive enzymes [15-17] there is distinct microbial origin for the digestive enzymes available in the gastrointestinal tracts of fish $[28,30,33,56,59]$. The growth of these microbes is dependent upon the ingested food by the fish, scaled off fragments from the mucosal epithelium and digestive secretions $[29,60,61]$. Fish tend to frequently take in large loads of microbes in their gut from the environment in which fish live and thereafter, some colonize in the gut of the fish forming persistent population adhering to intestinal mucosa and assist in the production of intestinal enzymes as exogenous source.

\section{Conclusion}

The results of the study enhance our understanding of the feeding patterns at different stratus levels within the available nutrition for the three fish species in polyculture systems. We are able to better understand how production results with each species targeting a particular stratus.

\section{Acknowledgements}

The authors extend their appreciation and gratitude to the Department of Fisheries Government of Haryana and University Grants Commission of the Government of India for providing funding for this project without which this work would not have been possible.

\section{References}

1. De Silva SS (1988) Reservoirs of Sri Lanka and their fisheries. FAO Fisheries Technical Paper, FAO, Rome, Italy. p. 298.

2. Ahmed M (1992) Status and potential of aquaculture in small waterbodies (ponds and ditches) in Bangladesh (No. 838). International Center for Living Aquatic Resources Management, Manila, Philippines.

3. Jhingran AG (1992) Fisheries status of aquaculture-based open water systems in India. In: Aquaculture Productivity, Oxford and IBH Publishing Co, New Delhi, India. pp: 295-306.

4. Chand BK, Goswami A, Biswas PK, Biswas P, Patra BC (2006) Effects of stocking levels of ducks on production of Indian Major Carps in village ponds under duck-fish integrated system in West Bengal state of India. Livestock Res Rural Dev 18: 6.

5. Da CT, Phuoc LH, Duc HN, Troell M, Berg H (2015) Use of wastewater from striped catfish (Pangasianodon hypophthalmus) pond culture for integrated rice-fish-vegetable farming systems in the Mekong delta, Vietnam. Agroecol Sust Food 39: 580-597.

6. Keshavanath P, Gangadhar B, Ramesha TJ, Priyadarshini M, Van Dam AA et al. (2015) Impact of substrates and fish stocking density on growth and production of the Indian major carp, Labeo rohita (ham.). J Aquacult Trop 30: $1-14$.

7. Pushpalatha KBC, Chandrasoma J, Liyanage HSWA, Fernando WAJR, Jayabahu JM (2016) Farming of Nile tilapia (Oreochromis niloticus) in backyard ponds in Sri Lanka: Culture practices, fish production and profitability. Sri Lanka J Aquat Sci 21: 27-34.

8. Efole Ewoukem T, Mikolasek O, Aubin J, Tomedi Eyango M, Pouomogne V, et al. (2017) Sustainability of fish pond culture in rural farming systems of Central and Western Cameroon. Int J Agr Sustain 15: 208-222.

9. Vollenweider RA, Kerekes J (1982) Eutrophication of waters. Monitoring assessment and control. Organization for Economic Co-Operation and Development (OECD), Paris, France.

10. Clarke KR, Warwick RM (1994) Change in Marine Communities: an approach to statistical analysis and interpretation. (2nd edn), Plymouth Marine Laboratory UK

11. Harsha TS, Malammanavar SG (2004) Assessment of phytoplankton density in relation to environmental variables in Gopalaswamy pond at Chitradurga, Karnataka. J Environ Biol 25: 113-116.

12. Tengjaroenkul B, Smith BJ, Caceci T, Smith SA (2000) Distribution of intestinal enzyme activities along the intestinal tract of cultured Nile tilapia, Oreochromis niloticus L. Aquaculture 182: 317-327.

13. Li Y, Ai Q, Mai K, Xu W, Deng J, et al. (2014) Comparison of high-protein soybean meal and commercial soybean meal partly replacing fish meal on the activities of digestive enzymes and aminotransferases in juvenile Japanese seabass, Lateolabrax japonicus (Cuvier, 1828). Aquacult Res 45: 1051-1060.

14. Zhai SW, Sun XW, Chen XH (2017) Effects of antimicrobial peptides surfactin administration on growth performance, intestinal digestive enzymes activities and some serum biochemical parameters of Orange-spotted Grouper (Epinephelus coioides) juveniles. Isr J Aquacult Bamid 69: 1-7.

15. Dhage KP (1968) Studies of the digestive enzymes in the three species of the major carps of India. J Biol Sci 11: 63-74.

16. Kawai S, Ikeda S (1972) Studies on digestive enzymes of fishes-II. Effect of dietary change on activities of digestive enzymes in carp intestine. Bull Jpn Soc Sci Fish 38: 265-270.

17. Das KM, Tripathi SD (1991) Studies on the digestive enzymes of grass carp Ctenopharyngodon idella (Val.). Aquaculture 92: 21-32.

18. Jose J, Surendran PK, Perigreen PA (1988) Studies on iced storage of cultured rohu (Labeo rohita). Fish Technol 25: 105-109.

19. Bisht A, Singh UP, Pandey NN (2014) Comparative study of seasonal variation in bacterial flora concomitant with farm raised fingerlings of Cyprinus carpio at Tarai region of Uttarakhand. J Environ Biol 35: 363-367.

20. Ghanbari M, Kneifel W, Domig KJ (2015) A new view of the fish gut microbiome: advances from next-generation sequencing. Aquaculture 448: 464-475.

21. Spanggaard B, Jørgensen F, Gram L, Huss HH (1993) Antibiotic resistance in bacteria isolated from three freshwater fish farms and an unpolluted stream in Denmark. Aquaculture 115: 195-207.

22. Fu J, Yang D, Jin M, Liu W, Zhao X, et al. (2017) Aquatic animals promote antibiotic resistance gene dissemination in water via conjugation: role of different regions within the zebra fish intestinal tract, and impact on fish intestinal microbiota. Mol Ecol 26: 5318-5333.

23. Loh JY, Ting ASY (2017) Bioprospecting gastrointestinal microflora of common fishes for disease control in aquaculture. In: Kalia V, Shouche $Y$, Purohit H, Rahi P. (eds). Mining of Microbial Wealth and MetaGenomics. Springer, Singapore.

24. Sugita H, Matsuo N, Shibuya K, Deguchi Y (1996) Production of antibacterial substances by intestinal bacteria isolated from coastal crab and fish species. $J$ Mar Biotechnol 4: 220-223.

25. Horsley RW (1973) The bacterial flora of the Atlantic salmon (Salmo salar L.) in relation to its environment. J Appl Bacteriol 36: 377-386.

26. Sugita H, Tsunohara M, Ohkoshi T, Deguchi $Y$ (1988) The establishment of an intestinal microflora in developing goldfish (Carassius auratus) of culture ponds. Microb Ecol 15: 333-344.

27. Cahill MM (1990) Bacterial flora of fishes: A review. Microb Ecol 19: 21-41

28. Lesel R, Fromageot C, Lesel M (1986) Cellulose digestibility in grass carp Ctenopharyngodon idella and in goldfish, Carassius auratus. Aquaculture 54: $11-17$

29. Saha AK, Ray AK (1998) Cellulase activity in rohu fingerlings. Aquac Int 6: 281 291.

30. Bairagi A, Ghosh KS, Sen SK, Ray AK (2002) Enzyme producing bacterial flora isolated from fish digestive tracts. Aquac Int 10: 109-121.

31. Rani S, Garg SK, Sabhlok VP, Bhatnagar A (2004) Intestinal enzyme activity and enzyme-producing microbial flora in relation to feeding behaviour in some brackish water teleosts. J Aquacult 12: 55-68.

32. Saha S, Roy RN, Sen SK, Ray AK (2006) Characterization of cellulase producing bacteria from the digestive tract of tilapia, Oreochromis mossambica (Peters) and grass carp, Ctenopharyngodon idella (Valenciennes). Aquacult Res 37: 380-388. 
Citation: Singh G, Bhatnagar A, Alok K, Ajay SA (2018) Enzymatic Profiling and Feeding Preferences of Catla: Catla Catla, Rohu: Labeo rohita and Mrigala: Cirrhinus mrigala in Rural Polyculture Ponds. J Aquac Res Development 9: 553. doi: 10.4172/2155-9546.1000553

33. Ray AK, Roy T, Mondal S, Ringo E (2010) Identification of gut-associated amylase, cellulase and protease-producing bacteria in three species of Indian major carps. Aquacult Res 41: 1462-1469.

34. FAO (2003) Aquaculture Production: Yearbook of Foods and Agriculture Organization of United Nations. Rome, Italy. pp: 1510-1511.

35. FAO (2006) State of World Aquaculture (2006) FAO Fisheries Technical Paper FAO, Rome, Italy.

36. Garg SK, Bhatnagar A, Kalla A, Johal MS (2002) Experimental ichthyology CBS Publishers, New Delhi, India.

37. Walter HE (1984) Methods of enzymatic analysis. Verlag Chemie, Weinheim, Germany.

38. Lowry OH, Rosebrough NJ, Farr AL, Randall RJ (1951) Protein measuremen with the Folin phenol reagent. J Biol Chem 193: 265-275.

39. Bernfeld P, Colowick SP, Kaplan NO (1955) Methods in enzymology. Academic Press Inc., New York, USA.

40. Colowick SP, Kaplan NO (1955) Methods in Enzymology, Academic Press Inc. New York, USA.

41. Dubois M, Gilles KA, Hamilton JK, Rebers PAT, Smith F (1956) Colorimetric method for determination of sugars and related substances. Anal Chem 28 350-356.

42. Barrington EJW (1957) The alimentary canal and digestion. In: Physiology of Fishes, Academic press, New York, USA. pp: 109-161.

43. Jhingran VG, Pullin RS (1985) A hatchery manual for the common, Chinese, and Indian major carps (No. 252). WorldFish, Penang.

44. Chakrabarty D (1998) Limnological studies on Lake Sinchal, a mountain lake in Darjeeling. Environ Ecol 16: 31-33.

45. Kumar S, Chakrabarti R (1998) Ontogenic development of amylase activity in three species of Indian major carps, Catla catla, Labeo rohita and Cirrhinus mrigala, in relation to natural diet. Asian Fish 10: 259-264.

46. Khabade SA (2015) Study of gut contents of major carps for their food habits from Sidddhewadi lake of Tasgaon tahsil of Sangli district Maharashtra. Int Fish Aquat 2: 1-4.

47. Panikkar P, Khan MF, Desai VR, Shrivastava NP, Sharma AP (2015) Characterizing trophic interactions of a catfish dominated tropical reservoir ecosystem to assess the effects of management practices. Environ Biol Fish 98: $237-247$
48. Mohanty RK (2004) Density-dependent growth performance of Indian major carps in rainwater reservoirs. J Appl Ichthyol 20: 123-127.

49. Majumder S, Ghosh P, Saha SK, Kumar S (2016) Study on food selection of Labeo rohita (Hamilton, 1822) by determining electivity index in periphyton based and periphyton free monoculture pond. J Adv Res 2: 04-07.

50. Khan RA, Siddiqui AQ (1973) Food selection by Labeo rohita (Ham.) and its feeding relationship with other major carps. Hydrobiologia 43: 429-442.

51. Sarbahi DS (1951) Studies on the digestive enzymes of goldfish Carassius auratus (Linn.) and large mouth black bass, Micropterus salmoides (Lacepede). Biol Bull 100: 244-257.

52. Phillips AM (1969) Nutrition, digestion, and energy utilization. Fish Physiol 1 391-432.

53. Fish GR (1951) Digestion in Tilapia esculenta. Nature 167: 900-902.

54. Yokoe Y, Yasumasu I (1964) The distribution of cellulase in invertebrates. Comp Biochem Physiol 13: 323-338.

55. Shcherbina MA, Kazlawlene OP (1971) The reaction of the medium and the rate of absorption of nutrients in the intestine of carp. J Ichthyol 11: 81-85.

56. Dutta D, Ghosh K (2015) Screening of extracellular enzyme-producing and pathogen inhibitory gut bacteria as putative probiotics in Mrigal, Cirrhinus mrigala (Hamilton, 1822). Intl J Fish Aquat 2: 310-318.

57. Bhattacharya T, Ray AK, Bhattacharya S (1987) Blood glucose and hepatic glycogen interrelationship in Channa punctatus (Bloch): A parameter of nonlethal toxicity bioassay with industrial pollutants. Indian J Exp Biol 25: 539-541.

58. Chatterjee N, Pal AK, Das T, Mohammed MS, Sarma K, et al. (2006) Secondary stress responses in Indian major carps Labeo rohita (Hamilton), Catla catla (Hamilton) and Cirrhinus mrigala (Hamilton) fry to increasing packing densities. Aquacult Res 37: 472-476.

59. Lindsay GJH, Harris JE (1980) Carboxymethylcellulase activity in the digestive tracts of fish. J Fish Biol 16: 219-233.

60. Lesel R (1993) Does a digestive active bacterial flora exist in fish? Colloques de I'INRA (France).

61. Bhatnagar A, Khandelwal S (2009) Enzyme producing bacterial flora isolated from digestive tract of fresh water teleost Catla catla (Hamilton). In: National Seminar on Science Education and Attraction of Talent for Excellence Research. Indian Science Congress Association, Bhopal, India. 